\title{
Transport and Inequalities
}

\section{Transport and social and health inequalities}

Low income is strongly associated with poor health (Benzeval et al, 2014; Rachele et al 2018). The United Nations' 17 Sustainable Development Goals (SDGs), adopted in 2015, are part of the 2030 Agenda for Sustainable Development (www.un.org/sustainabledevelopment/sustainabledevelopment-goals/). These are designed to reduce inequalities between and within countries, particularly low income countries. The same year, the Paris Agreement on climate change was adopted by 195 countries, entering into force in November 2016 (https://ec.europa.eu/clima/policies/international/negotiations/paris en). Transport policies are integral to both these global initiatives. Sustainable Development goals of particular relevance to transport and health include:

- 1 No poverty;

- 3 Good health and well-being;

- 10 Reduced inequalities;

- 11 Sustainable cities and communities;

- 12 Responsible consumption and production;

- 13 Climate action; and

- 15 Life on land.

In general, transport policies that are good for health and reduce inequalities are also low carbon, sustainable approaches, particularly through promoting active travel and public transport and reducing private car use (Mindell et al, 2011). In most countries, motor vehicles are owned and used more by the rich and the adverse health effects, such as injuries, air and noise pollution, and community severance, are experienced primarily by those with fewer resources, whether financial or educational (Lowe et al., 2011; Noland and Quddus, 2004). With a philosophy of 'leaving no-one behind', the intention is that every vulnerable group is included or even targeted by actions to implement the SDGs. Unhealthy environments are estimated to contribute $23 \%$ of global deaths and $22 \%$ of global disability-adjusted years, with non-communicable diseases the major consequences. Outdoor air and noise pollution, road travel deaths, falls, and physical inactivity are some of the ways that transport contributes to this global burden of disease (Prüss-Ustün et al, 2017).

Poorer people often have worse access to jobs, education, goods, and services because of lack of options for transport, particularly in places planned assuming private car use (Rachele et al, 2018, Editor's choice). Walking, or cycling, are often the only affordable travel options, particularly in low and middle income countries (Dimitriou and Gakenheimer, 2011), although higher socio-economic groups in the Netherlands walked and cycled more than other groups (Gao et al, 2017). One potentially beneficial aspect is that those who walk or cycle for transport have a lower body mass index (Turrell et al, 2018), although it can take years for substantial changes to occur after stopping car use (Smart, 2018). Although this may be important in the many areas worldwide where obesity is higher among more disadvantaged sectors of the population, as is seen in many OECD countries (https://www.oecd.org/els/health-systems/Obesity-Update-2017.pdf), there is a balance to be struck between beneficial physical activity and unduly time-consuming journeys, particularly among the poorest residents of often informal residential areas (Barter, 2001; Starkey and Hine, 2014). Kim and Cubbin (2018) report that poor mothers who felt their neighbourhoods were unsafe were those who were most likely to walk or cycle. A better option is to reduce the need for private cars for everyone (Rachele et al, 2018). As Enrique Peñalosa said: "An advanced city is not one where even 
the poor use cars, but rather one where even the rich use public transport"

(https://www.ted.com/talks/enrique penalosa why buses represent democracy in action/discus sion). Universal access to subsidised public transport could therefore reduce inequalities. Laverty et al (2018) used a cohort study of older people in England to show that take up of a free bus pass was equitable across socio-economic groups and was strongly linked to public transport use by older people. As previous research has found, use of the bus pass, in turn, has protective factors for older people against ill health, especially obesity (Webb et al., 2011) and contributes to wellbeing (Green et al., 2014).

Reducing car dependence can decrease inequalities in access at the same time as reducing the burden of adverse effects imposed by motor vehicle users on others. However, Duran et al found that public bicycle-sharing schemes were located in wealthier, centrally located areas and their users had above average education levels. Similarly, complete streets, which are promoted to provide good environments for users of all forms of transport and which should therefore make environments more equitable, tend to increase the value of local housing. This can be considered beneficial and an economic argument for investing in complete streets (Yu et al, 2018). However, it could therefore increase not decrease inequalities.

\section{Transport, impairments, and illness}

As well as the poor, another group often overlooked are people with impairments, for whom society and the environment are often disabling (Thomas, 2014). Kett and Deluca (2016) have highlighted the difficulty that children with disabilities have in accessing education in low income countries. Andrews and colleagues (2018) point out that few transport strategies mention disabled cyclists, and few images show non-standard cycles. Disability and illness are also associated with 'non-travel', as is age (Corran et al, 2018). Urban residents in the USA with health conditions that limit travel, particularly driving, are more likely to limit their travel than their rural counterparts (Henning-Smith et al, 2018).

Many of the papers we publish focus on transport interventions and habits that promote good health. However, this volume has a number of papers examining transport and disease. Given that both orthopaedic surgery and air travel are known risk factors for thromboembolic disease, such as deep vein thrombosis (blood clots in the legs) and pulmonary emboli (blood clots that break off, circulate, and become lodged in the lungs, interfering with oxygen exchange), Donnally et al (2018) reviewed the available evidence on the risks of air travel after orthopaedic surgery. Their aim was to be able to advise patients how long they should wait after such surgery before flying. They found few studies but concluded that flying after hip and knee replacement is probably safe, provided suitable prophylaxis is used, and fractures of the arm pose not increased risk. Other conditions, however, either result in high risk or have not been studied sufficiently.

Kim and Ahn (2018) found that air pollution from buses can exacerbate severe asthma in older people although they found no effect on other cases of asthma. Air pollution emissions in 2005 were estimated to cost the USA $\$ 1.0$ trillion, with on-road emissions from vehicles accounting for $14 \%$ of this (Heo et al, 2016). Increasing emission standards for vehicles - if adhered to (Lancefield 2017)can contribute to a great extent to reducing air pollutant emissions and therefore the concentrations of toxic substances to which people are exposed. The Euro VI standards for buses are particularly important, both to reduce emissions while maintaining public transport [transit] services and demonstrating what could be achieved for cars and vans (Begg 2017). Unfortunately, countries without access to sufficiently high standard diesel fuel cannot use Euro VI buses (for example Colombia). Furthermore, such improvements are easily overwhelmed by increases in motorised travel, particularly as Euro 6 diesel cars emit an order of magnitude more oxides of nitrogen $\left(\mathrm{NO}_{\mathrm{x}}\right)$ per passenger than a Euro VI bus (and probably more in real life). Similarly, private vehicles contributed more emissions of air pollutants than public transport in Delhi, although goods vehicles contributed disproportionately to pollutant emissions (Jain et al, 2016). Individuals' travel patterns 
can be modified: the London congestion charge is estimated to have reduced air pollution, with nontrivial predicted health benefits (Tonne et al, 2008) but the evidence for the effects of traffic management strategies on air pollution remains weak (Bigazzi and Rouleau, 2017). Jain and colleagues (2016) found that a combination of measures, including stringent emission limits, more public transport options, higher parking fees, and regulated public transport speed, will be required to reduce air pollution in cities in developing countries. The Sustainable Development Goals and Climate Change agreements have many difficulties in achieving their aims but adequately funded transport policies can make significant contributions.

\section{References}

Andrews N, Clement I, Aldred R. Invisible cyclists? Disabled people and cycle planning - A case study of London. J Transp Health. 2018;8: https://doi.org/10.1016/i.jth.2017.11.145

Barter P. Linkages Between Transport \& Housing for the Urban Poor: Policy implications and alternatives. Nairobi: UN-HABITAT,2001.

Begg D. Why the Euro VI bus is essential to the success of Clean Air Zones. https://greenerjourneys.com/blog/euro-vi-bus-essential-success-clean-air-zones/ 14 Nov 2017. (Accessed 28 Dec 2017)

Benzeval M, Bond L, Campbell M, Egan M, Lorenc T, Petticrew M, Popham F. how does money influence health? York: Joseph Rowntree Foundation, 2014. https://www.jrf.org.uk/sites/default/files/jrf/migrated/files/income-health-poverty-full.pdf

Bigazzi AY, Rouleau M. Can traffic management strategies improve urban air quality? A review of the evidence. J Transp Health. 2017;7 Part B:111-124. https://doi.org/10.1016/i.jth.2017.08.001

Corran P, Steinbach R, Saunders L, Green J. Age, disability and everyday mobility in London: An analysis of the correlates of 'non-travel in travel diary data. J Transp Health. 2018;8:

https://doi.org/10.1016/j.jth.2017.12.008

Dimitriou HT, Gakenheimer R (eds)UN. Urban transport in the developing world. A handbook of policy and practice. PLACE: Elgar Publishing, 2011.

Donnally CJ III, Rosas S, Sheu JI, Damodar D, Buller LT, Cohen-Levy WB, Hernandex FJ, Hernandex VH. Air travel and thromboembolic events after orthopaedic surgery: Where are we and where do we need to go? J Transp Health. 2018;8: https://doi.org/10.1016/j.jth.2017.11.150

Duran AC, Anaya-Boig E, Shake JD, Totaro Garcia LM, Machado de Rezende LF, de Sá TH. Bicyclesharing system socio-spatial inequalities in Brazil. J Transp Health. 2018;8:

https://doi.org/10.1016/i.jth.2017.12.011

Gao J, Helbich M, Dijst M, Kamphuis CBN. Socioeconomic and demographic differences in walking and cycling in the Netherlands: How do these translate into differences in health benefits? J Transp Health. 2017;6:358-365. https://doi.org/10.1016/i.jth.2017.06.001

Green, J. ,Jones, A. and Roberts, H. (2014) More than A to B: the role of free bus travel for the mobility and wellbeing of older citizens in London. Ageing and Society, 34 (03). pp. 472-494. ISSN 0144-686X

Henning-Smith C, Evenson A, Kozhimannil K, Moskovice I. Geographic variation in transportation concerns and adaptations to travel-limiting health conditions in the United States. J Transp Health. 2018;8: https://doi.org/10.1016/i.jth.2017.11.146

Heo J, Adams PJ, Gao HO. Public Health Costs of Primary PM2.5 and Inorganic PM2.5 precursor Emissions in the United States. Environ. Sci. Technol. 2016;50:6061-6070.

DOI:10.1021/acs.est.5b06125 
Jain S, Aggarwal P, Sharma P, Kumar P. Vehicular exhaust emissions under current and alternative future policy measures for megacity Delhi, India. J Transp Health. 2016;3:404-412. https://doi.org/10.1016/i.jth.2016.06.005

Kett M, Deluca M. Transport and access to inclusive education in Mashonaland West Province, Zimbabwe. Social Inclusion. 2016;4:61-71. Doi: 10.17645/si.v4i3.502

Kim D, Ahn Y. Built environment factors contribute to asthma morbidity in older people: A case study of Seoul, Korea. J Transp Health. 2018;8: https://doi.org/10.1016/i.jth.2017.12.002

Kim Y, Cubbin C. Residence in unsafe neighbourhoods is associated with active transportation among poor women: Geographic Research on Wellbeing (GROW) Study. J Transp Health. 2018;8:

Lancefield N. New cars face tougher emissions tests in bid to stop manufacturers falsifying results. Independent. $31^{\text {st }}$ August 2017. www.independent.co.uk/news/uk/home-news/car-emission-testspollution-volkswagen-false-results-prevention-a7923196.html

Laverty A, Millett C, Webb E. Take up and use of subsidised public transport: evidence from the English Longitudinal Study of Ageing. J Transp Health. 2018;8:

Lowe, C., Whitfield, G., Sutton, L. and Hardin, J. (2011) Road User Safety and Disadvantage. Department for Transport, UK. Road Safety Research Report 123. London, UK: Department for Transport. Available at http://citeseerx.ist.psu.edu/viewdoc/download?doi=10.1.1.454.9618\&rep=rep1\&type=pdf (last accessed $30^{\text {th }}$ January 2018)

Mindell JS, Cohen JM, Watkins S, Tyler N. Synergies between low carbon and healthy transport policies. Proceedings of the Institution of Civil Engineers - Transport. 2011;164:127-39.

Noland, R B., Quddus, M. A., (2004), A Spatially Disaggregate Analyses of Road Casualties in England, Accident Analysis and Prevention, 36 (6), pp.973-984.

Prüss-Ustün A, Wolf J, Corvalán C, Neville T, Bos R, Neira M. Diseases due to unhealthy environments: an updated estimate of the global burden of disease attributable to environmental determinants of health. J Public Health. 2017;39:464-475. Doi:10.1093/pubmed/fdw085

Rachele JN, Sugiyama T, Turrell G, Healy AM, Sallis JF. Automobile dependence: A contributing factor to poorer health among lower-income households. J Transp Health. 2018;8:

https://doi.org/10.1016/j.jth.2017.11.149 EDITOR'S CHOICE

Smart MJ. Walkability, transit and body mass index: A panel approach. J Transp Health. 2018;8:

Starkey P, Hine J. Poverty and sustainable transport. How transport affects poor people with policy implications for poverty reduction. A literature review. UN Habitat Partnership on Sustainable Low Carbon Transport, 2014.

Thomas C. 'Disability and Impairment'. Chapter 2 in Swain J, French S, Barnes C, Thomas C (Eds). Disabling barriers - enabling environments. $3^{\text {rd }}$ edition. London: Sage Publications Ltd., 2014.

Tonne C, Beevers S, Armstrong B, Kelly F, Wilkinson P. Air pollution and mortality benefits on the London Congestion charge: spatial and socioeconomic inequalities. Occup Environ Med. 2008;65:620-627. Doi: 10.1136/oem.2007.036533

Turrell G, Hewitt BA, Rachele JM, Giles-Corti B, Brown WJ. Prospective trends in body mass index by main transport mode, 2007-2013. J Transp Health. 2018;8: https://doi.org/10.1016/i.jth.2017.12.004

Webb, E, Netuveli G, Millett C. (2011) Free bus passes, use of public transport and obesity among older people in England. Journal of Epidemiology and Community Health. 2011;66:176-180. doi:10.1136/jech.2011.133165 
Yu C-Y, Xu M, Towne SD, Iman S. Assessing the economic benefits and resilience of complete streets in Orlando, FL: A natural experimental design approach. J Transp Health. 2018;8:

https://doi.org/10.1016/i.jth.2017.11.005 